\title{
A találkozás perszonális momentuma: válaszom a másiknak
}

\author{
(részlet)
}

A definiálatlan és sokszínü közös lehetőség - egy elözetesen birtokolt örömteli haladékon, vagy a bizonytalanság fáradságos megszüntetésén keresztül - egy jól körülhatárolható tervben konkretizálódik, és megérkezik a válasz. Legyen ez teremtő vagy hétköznapi, morálisan értékes vagy aljas: mit jelent ez a találkozás szemszögéből? Azt mondanám, hogy a találkozás vonatkozásában a válasz egy konfiguratív és esszenciális aktus. Csak a válasszal kezdi elnyerni a találkozás saját formáját: a másik definitíve kezd ,a másik”, én végérvényesen ,én”, a világunk véglegesen a „mi világunk” lenni. Azelőtt, hogy válaszolnék neki, a másik nem volt számomra egy teljesen befejezett ontológiai alak: csak egy pszichofizikai valóság volt — arc, mosoly, hang a sötétben, selyem suhogása —, melynek még befejezetlen jelentése folytathatta az utat, és megkaphatta az önmagukban igen különbözö kiegészítéseket. Az esti homályban egy katonai állásnál járok. Az őrszem, aki meghallotta lépéseimet, nekem szegezi szokásos kérdését: „Ki az?” Szavai révén tapasztalatot nyertem a másikról - nem szükséges most megismételnem a pszichofiziológiai folyamat leírását, amellyel ez végbement. Mit fogok tenni ezekkel a szavakkal szemben? Válaszolni fogok vagy sem? Ha nem válaszolok neki, az őrszem — számomra és önmagában — továbbra is a jelenlegi befejezetlen dolog marad: egy kérdő hang egy láthatatlan és bizonytalan jövő felé. Amennyiben joviálisan válaszolok, akkor ez a hang talán egy fiatalember alakjában konkretizálódik, aki a barátommá kezd válni. Ha kihívóan válaszolok, meglehet ez az ember dühössé és ellenségessé változik. Elég ez a nagyon egyszerü és átlátható példa, hogy felhívja a figyelmet egy általános igazságra: válaszom előtt a másik nekem valóban egy alaktalan és befejezetlen lény. Válaszommal és azzal a szándékkal, hogy a „találkozás” kiteljesedhessen egy „kapcsolatban”, a másik ténylegesen egy olyan ember számomra, aki egy jól meghatározott formát kezd felölteni. A puszta „kérdező hang” elkezd „ez az ember” lenni; egyes esetekben „,ez az ő”, más esetekben „ez a te”. Ontológiai szemszögböl ez a kiteljesedés azon jegyek megjelenésében áll, amelyekben megmutatkozik az, aki ténylegesen a másik számomra. Szakmailag megközelítve: válaszom 
közös meghatározottságot adott a másik lényegét illetően, és lényeget adott közös létezésünknek. Ezért mondtam, hogy a válaszadás aktusa egyidejüleg „konfiguratív” és „esszenciális”. Alakkal és lényeggel felruházva, a másik nemcsak a „másik én” másságát mutatja fel előttem, hanem a „másik, aki én”, a ,másik” másikságát is. Vele való eredendő mi-ségem „mimásikság"-gá (nos-otredad) lett.

Éppúgy történik a másikról nyert tapasztalatom, mutatis mutandis, mint az önmagamról nyert tapasztalatom. A találkozás elött irreflexív tudat voltam: életem én-érzés nélküli volt. A másik észlelése hirtelen „a miénk” élményét hozta létre bennem, amit mi-ségnek nevezek. Ez, mint tudjuk, hamarosan szétválik egyrészről ,az enyém”, másrészről ,a tiéd” vagy „,az övé” élményére. Talán ezzel azt akarom mondani, hogy tudatom szubjektivitása egyértelmüen eljutott az „én” léthez? Semmiképpen. Ez csak akkor fog megtörténni bennem, amikor meghozom a döntést a másiknak adott válaszról — más szavakkal: elkezdem „elfoglalni a helyet” átellenben „az idegennel" - és még inkább akkor, amikor egy effektív - külső vagy belső - választ adtam a másiknak. Ekkor leszek, mint Münsterberg mondaná, stellungsnehmendes Ich, „,inceptív” vagy „pozicionális én”, és egyidejüleg „empirikus én”, akit a konkrét szituációm determinál: egy én, aki hall és hallgat; egy én, aki lát és tesz ilyen-olyan dolgokat, stb. A másik kifejeződése - ezért: a másik — és a neki adott szabad válaszom közösen meghatározzák formám és esszenciám. A másik aktuális „mi-másikság”ával átellenben én a „mi-énség” (nos-yoidad) aktusában vagyok, és ez alatt — valóságom azon rétegében, amelyben már nem azt mondom, hogy „én”, hanem azt, „saját magam” — a „mi-magunkság”-om (nos-mismidad) aktusában. Válaszom, saját létemre vonatkozóan is, egy konfiguratív és esszenciális aktus.

Végül, ugyanez mondható el a „mi világunk” vonatkozásában is. Néhány oldallal korábban mondtam azt, hogy a másikkal való találkozásban világom „kétszemélyes otthon”, vagy a „találkozás otthona” lesz. A világ realitásai és lehetőségei hirtelen a „,az előttem levő másik” valóságtengelye körül rendeződnek el. A dolgok ekkor nincsenek közel hozzám vagy távol tőlem - sem közel hozzá vagy távol tőle, ahogy Sartre, a kezdeti mi-ség szisztematikus félreismerője többször megerösítette - hanem közel „hozzánk” vagy távol „tőlünk”; és ahogy a távolságok elrendeződnek, ugyanígy mindenféle lehetőségei is, amelyek állandóan megmutatkoznak a „mi” világgal való kapcsolatunkban. Azonban azt is tudjuk, hogy ez az otthon puszta határozatlanság, radikális ambivalencia. Ha a másik és én találkozunk a vonaton, a „mi” egzisztenciális távolságunk az állomástól, 
ahol el kell válnunk, óriási vagy minimális lehet számunkra, a közöttünk lévő reláció esélyei szerint; és ezzel analóg módon történik minden más. A felelet előtti mi-ség, mondtam korábban, otthon, amelynek a mélyén az együttmüködés ígérete és a konfliktus fenyegetése között, egy határtalan közös lehetőség közös duális projektummá lesz. S ez így történik, amíg válaszom formát és esszenciát nem tulajdonít a találkozás első bizonytalan otthonának, természetesen nem végleg meghatározott formát és lényeget, melyek ugyanakkor alávethetők egy többé-kevésbé pontos leírásnak. Válaszommal tehát egy konkrét formával addig nem bíró otthon ontológiai építésze vagyok, mert válaszom előtt, csak közös lehetőségek puszta orientációja volt. Az én és a másik távolsága a búcsúállomástól definitíve óriási vagy minimális lesz, mihelyt én — vagy ő - válaszoltunk találkozásunkra.

Nyilvánvaló, hogy válaszom természete erősen függ attól, amit számomra a másik megjelenése jelent. Csak ha nagyon szent vagyok, akkor fogok ép arcom felkínálásával válaszolni annak, aki egy pofont adva bukkant fel előttem. Azonban válaszom természetét éppúgy meghatározza a másik alkalomszerü viselkedése — ami számomra sohasem lesz „objektív” viselkedés, legkevésbé annak kezdetén —, mint ahogy saját szabadságom: egy olyan szabadság, amelynek hatókörét hármas tény korlátozza és határozza meg - ember vagyok, ilyen ember vagyok, és szituációban lévő vagyok. Nem itt van egy arról szóló részletes tanulmány helye, miképpen korlátozzák és határozzák meg az emberi szabadságot a genotipikus, fenotipikus és szituacionális tényezők, de talán nem felesleges újból aláhúzni az élet első éveinek óriási, és egyre jobban felismert jelentőségét a pszichikai tulajdonságok kifejlődésében, melyek szabályozzák a másikkal való relációnkat. Példaként idézem Margaret Mead antropológiai kutatásait Új-Guinea vademberei között. ${ }^{1}$ Új-Guineában három törzs található: az arapesh, a mundugumor és a tchambulí. Az arapeshek békeszeretőek és nem ismerik a kompetitív rivalizálást; a mundugumorok viszont agresszívak; a tchambulík között pedig a férfiak foglalkoznak azokkal a munkákkal, amit mi nyugatiak nőinek szoktunk nevezni (tánc, díszítés, hímzés), és a nők harcolnak, vadásznak, halásznak. Margaret Mead tanulmányai bebizonyították, hogy e három nép szociális viselkedése - a mód, ahogy tagjai ,válaszolnak" másokkal való találkozásukra — a gyerekek első éveiben kapott nevelés által meghatározott. „Egy aprólékos megfigyeléssel, ami laboratóriumi tapasztalatnak mutatkozik -

${ }^{1}$ M. Mead: Sexo y temperamento (Buenos Aires, 1947). 
kommentálja Rof Carballo -, ezek a tanulmányok bebizonyítják nekünk, hogy a gyermekkor elején, az archi- és paleoencephalon „benyomása” jellegzetes és végleges pecsétet ad a felnőtt embernek, és ezért az egész kultúrának, amelyhez tartozik. Később a társadalom rögzíti és állandósítja ezeket a jegyeket, nem a neveléssel, ez sokkal később jön, csak valami olyannal, ami nem tünt fontosnak: a gyermek szoptatásával vagy simogatásával; azzal, hogy megtanítja záróizmainak szabályozására; a megfoghatatlan érzelmi légkörrel, ami fellép körülötte életének első éveitől harmadik vagy negyedik évéig." ${ }^{2} \mathrm{Az}$ ember jelentős mértékben aszerint válaszol a másiknak, ami gyermekkorában érte. Már említettem, hogy a találkozás létté válik, és ez a szabály attól a pillanattól kezd beteljesülni, amelyben a világra jön. ${ }^{3}$

A másik észlelésére adott válaszok végtelen variációi önmagukban nagyon különböző kritériumok elrendeződésével jöhetnek létre: a válaszadó szerv sajátossága (hang tekintet, gesztus); maga a válasz tartalma (harag, öröm, unalom); a találkozásra vonatkozó ítélőképessége, és más különbözö szempontok. A következő fejezetben a találkozás deficiens formáit tanulmányozva megvizsgáljuk azt a szerepet, amelyet minden egyes fö adó és vevő szerv játszik benne. Most, azzal a feltétellel, hogy később visszatérek a témára, röviden jelzem a válasz különböző tipikus módjait, az interperszonális reláció értelmére gyakorolt hatása szerint.

Úgy gondolom, ezek a módok háromra redukálhatók: a válasz, amely elutasítja a találkozást, amely megnyújtja, és amely elfogadja azt. Elutasítani a találkozást egy válasszal, nem ugyanaz, mint megtagadni egy kitérő csend által. De lehetséges-e, hogy egy válasz megsemmisítse a másikkal való találkozást? Nem hiszem. Ha azt mondom a másiknak: "Hagyjon, nem akarok beszélni önnel", ettől még nem hagytam abba a találkozást azzal, akit el akarok különíteni magamtól. Jó vagy rossz — jó, amikor egy alkalmatlankodóról; rossz, amikor egy nélkülözőről van szó -, az elutasító találkozás nyoma sokáig fog tartani bennem. Mint species, ha jól emlékszem az epizódra; mint habitus, ha nem emlékszem a részleteire vagy elfelejtettnek hiszem. Hányszor nem bukkan fel bennem - rosszul

${ }^{2}$ Cerebro interno y mundo emocional, 393. (Barcelona, 1952) Ld. még: Uő: Urdimbre afectiva y enfermedad. (Barcelona, 1961)

${ }_{3}^{3}$ „Egy rossznak a létezése mindig azon alapul - legyen az empirikusan bizonyított vagy sem -, hogy mindenkiből vétkes módon hiányzik a rosszaság hordozója iránti szeretet." (Scheler: Esencia y formas de la simpatía. 234. Buenos Aires, 1942) Az ilyen állítás árnyalatokat és fenntartásokat kíván meg, de lényegét illetően egy nagyon fontos igazságot tartalmaz. 
érezvén magam, megakadályozva szellemem „megérését” abban, mit szándékozom tenni - valamely kifejezetten elutasító találkozás lenyomata? Ha így vagy úgy mondom: "Hagyjon, nem akarok beszélni önnel", mennyit veszítettem életemben? Pathologie de l'éloignement cím alatt M. Chastaing írt arról finom pszichológiai és etikai bonyolultságról, amely magába foglalja a nélkülözővel való találkozást elutasító aktust. ${ }^{4} \mathrm{~A}$ tőlem alamizsnát kérő koldus hallgatólagos vagy kifejezett elutasításának önigazolása miatt, taktikailag gyermeknek, primitívnek, neurotikusnak skizofrénnek, álmisztikusnak tettetem magam. Kétségtelen, nem jelentéktelen dolog a kockázat: elutasítani a találkozást valakivel, aki hozzám fordult.

Kevesebb pszichológiai és morális jelentősége van a találkozást megnyújtó válasznak. ${ }^{5}$ Haladjunk tehát az előbb megnevezett harmadik típushoz: az elfogadó válaszhoz. Ezzel elfogadom a másikkal való találkozást és a vele járó következményeket. Azóta, hogy eldöntöttem a válasz kimondását, de sokkal inkább a kimondás után - és most már érthetö, hogy ennek a „kimondásnak” nem kell szó szerint léteznie - a másik és én világosan és végeredményesen duális én-az (dúo), vagy duális én-te (díada) vagyunk. Talán egy látható formulával - egy „köszönéssel”- pecsételtük meg találkozásunk bevégződését. ${ }^{6}$ Meglehet, közös és kölcsönös elfogadásunk nélkülözött minden protokollt, ahogy akkor történik, amikor a találkozás nem szünt meg egy néma tekintetváltás lenni. Ez mindegy. A fontos és döntő az, hogy elfogadó válaszommal formát és tartalmat adtam a találkozásnak. Mai közhellyel szólva: a másik vonatkozásában én már egy „elkötelezett” ember vagyok.

Az elfogadó válasz által létrejött teremtett viszony figyelmes vizsgálata még négy lényegi momentumot enged megkülönböztetni a maga struktúrájában: a specifikus formát (hatalmi és alárendeltségi reláció vagy egzisztenciális egyenlöség); a tartalmát (az, amit a reláció idején beszélnek, tesznek, gondolnak és éreznek a benne résztvevők); az összekötő kapcsolatot (végső fokon a szeretetet vagy a gyülöletet); és a determináló instanciát (a szabadságot: szabadságom, egybevetve a másikéval).

\footnotetext{
4 „Du Lévite au Samaritain. Pathologie de l'éloignement” In.: L'amour du prochain. 237258 (París, 1954)

5 Nélküle nem lenne lehetséges a diplomácia. Egy igazi emberek közötti találkozás befejezése halogatásának müvészete, talán nem tartozik hozzá a diplomáciai élet rutinjához? ${ }^{6}$ Ami a köszönés jelentésére vonatkozik, ld. Ortega: El hombre y la gente (Madrid, 1957); és J. H. Van den Berg „Der Händedruck” című tanulmányát (In.: Rencontre. Ecounter. Begegnung. 31-39, Utrecht-Antwerpen, 1957).
} 
„Nem veszekednek ketten, ha egy nem akar”, mondja a népi bölcsesség. Az, hogy szeressem és ne gyülöljem a másik konkrét realitását, hogy ez a szeretet barátság legyen, és ez a barátság különféle tettekben nyilvánuljon meg, ezek olyan dolgok, amelyek nagyon tág mértékben függenek szabad akaratomtól. Az olyan kifejezések, mint ,gyülölöm: az iránta érzett gyülöletem erősebb, mint én", mindig nyilvánvalóan hiperbolikusak. Nincs szó ezzel a biológiai konstitúció fontosságának csökkentéséről (moral insanity, pszichopatologikus eredetú morális rosszakarat), sem a nevelés jelentőségének kisebbítéséről a társadalmi és érzelmi habitusok eredetében (Margaret Mead, Spitz kutatásai, stb.); de, szélsőséges esetektől eltekintve, szabad akaratának gyakorlása folyamán az ember mindig ellenszegülhet saját habitusainak vagy belsővé teheti öket. ${ }^{7}$ Sőt, amikor Lady Macbeth lelkében a „rossz hajlam” lüktet, ahogy önmagának mondja, megírhatta volna-e a tragédiáját Shakespeare, ha Lady Macbeth nem lett volna képes ellenállni az ilyen ösztönöknek, és legyözni azokat? Ami te vagy a számomra, és ami én vagyok a számodra, természetesen attól függ, hogy te és én mik vagyunk, valamint a közös szituációnktól; de attól is, hogy mi ketten mit akarunk, vagyis szabadságunktól. Az én szabadságom és a tiéd, közösen, lényegileg határozzák meg relációnk specifikus formáját, tartalmát és az összekötő kapcsolatot. Szabadságom szempontjából tehát az egyszerüség kedveért még nem véve figyelembe a másik szabadságát és válaszát - a reláció és a találkozás három fó módja:

1. Válaszommal a másik objektum lesz számomra: tárgyi reláció;

2. Válaszommal a másik, mint személy jelenik meg számomra - és én a számára: perszonális reláció;

3. Válaszommal felebarát leszek a másik számára - és a másik az én számomra, ha viszonozza nekem: felebaráti reláció.

A későbbi fejezetekben tanulmányozni fogom az emberközti relációk e három tipikus módját. Most szólni kell néhány szót a találkozás világának szerveződéséről.

A másiknak adott válaszommal a találkozás beteljesül. Ettől kezdve a vele való relációm megszünik mint „találkozás”, és átfordul „kapcsolattá”. Bár az interperszonális kapcsolat, mint látni fogjuk, még minimális valóságára

\footnotetext{
${ }^{7}$ Mindez a szabadság „fokainak” és „szintjeinek” nagyon komoly pszichológiai és morális problémáját veti fel; jogi nyelven: az „enyhített” vagy "csökkentett felelösségét”. Jelenleg erre nem térhetek ki.
} 
korlátozódva — azaz a másikkal való viszonyunkban, amely találkozásunk pillanatától elbúcsúzásunk pillanatáig tart —, sem lehet eredendő, ha időnként nem villan fel benne valamilyen új találkozás szikrája a beszélgető társak között. Miközben a másik és én együtt vagyunk, a világ a „mi világunkká” szerveződik. A világ tengelye ekkor számomra - és a másik számára - az a biperszonális övezet, amelyet a „találkozás otthonának" nevezek. Generikusan elgondolva: miben áll a találkozás által létrehozott világ e szerveződése?

Úgy gondolom, hogy a találkozás világának ontikus struktúrájában három, egymástól világosan elhatárolható terület fonódik egymásba: A „mi”, az „ök” és az „az” területe.

A mi területe most a te és az én (vagy a már ismert feltételekkel az ő és az én) által egyesített. Válaszommal elérkeztem ahhoz, hogy én legyek, a másik pedig ahhoz, hogy te legyen. De én a mi-énségben (nos-yoidad) vagyok én; a másik a mi-másikságban (nos-otredad) és a mi-teségben (nostuidad) te, mert duális én-az-t (dúo), vagy én-te-t (díada) érezve, mindegyik a másikra utalt a mi-ben, amelyet együtt konstituálunk. Az „én és te" formája alatt a mi létezik. E szerint, a gyermekkor elmúltával, ha egyszer megtesszük saját énünk igéző és nehéz felfedezését, a „mi” személyes névmás közvetlen módon öt különböző valóságra utalhat: 1. A generikus mi-ség, amely kezdetben (amikor vele találkozva „hasonlóként” élem meg a másikat) vagy ezt követően (amikor később azt gondolom, hogy ö és én emberek vagyunk) megteremti közöttünk közös emberi mivoltunkat. 2. A felelet előtti duális mi-ség, amely összeköt engem a másik egyedi személyével, a te-és-én, amelyet együtt formálunk azelött, hogy a másik te lenne, és én én lennék. 3. A felelet utáni viszony a másikkal, amikor ő már te nekem. ${ }^{8}$ 4. A másikkal való felelet utáni viszony, amikor a másik egy ő a számomra. 5. További reláció, egyrészröl a mi tengely, amelyet te és én alkotunk, másrészről az ő (vagy ők) valósága között. Egy rövid megjegyzés e harmadik realitásra vonatkozóan: mihelyt egy duális mi tagjai, te és én „én-a-mi-ben” és „te-a-mi-ben” vagyunk. Később tanulmányozni fogjuk a „-ben” tulajdonképpeni jelentését, fontosságát és struktúráját.

Az ök területét az összes többi ember alkotja, tartozzanak hozzá azon kevesek, akik téged és engem jelenleg érdekelnek (barátok vagy ellenségek, akikröl beszélünk); legyenek ezek részei ama legtágabb csoportnak,

${ }^{8}$ A későbbi fejezetekben látni fogjuk, hogy ez a felelet utáni $m i$, a te-vel különböző formákat ölthet: a duális én-az kooperatív mi-je; a szerető duális én-te-t közösen magában foglaló $m i$; és a gyűlölet duális én-te-jét, szintén közösen magában foglaló mi. 
amelyet az általunk nem említett ismeröseink képeznek; vagy maradjanak az összes ember mérhetetlen tömegében — a Péguy-féle „hatalmas anonimitás" — akiket te és én nem ismerünk, Ádámtól az emberiség végéig. A mi előbb feltüntetett öt értelmének utolsó pontja, ahogy említettem, megnevezi egyrészről a te és én közötti kapcsolatot, másrészről a differenciáltabb vagy alaktalanabb ők együttesét.

A duális mi utalása az ők területére lehet individualizált, kollektív, vagy generikus. Első esetben az ők az ő-re redukálódik, és a relációnk (te és én az egyik oldalon, ő a másikon) egy hármas én-az-t (trío), vagy ha a kapcsolat a három között bensőséges, egy hármas én-te-t (tríada) alkot. Parciális szemszögéből (az emberközti kapcsolatnak tisztán objektiváló és vizuális jelleget tulajdonítva), Sartre nagyon találó módon analizálta azt a nóvumot, melyet a pár (couple) előtt megjelenö harmadik vezet be, legyen ez duális én-az vagy én-te kapcsolat. Azonban már azt is tudjuk, hogy Sartre okosságát és fineszességét integrálni kell az emberek közötti kapcsolatok egy szélesebb koncepciójába. Ezt a későbbiek során kell megtenni. Ha a mi utalása az ők-re kollektív, az ők, többé-kevésbé pontosan elhatárolt személyek csoportját alkotják. Ez történik, amikor mi (te és én) látjuk azokat, akik elfoglalják a kávéház másik asztalát; amikor ,a Pérezekről” vagy „a franciákról” beszélünk. Végül, a generikus utalás lehet kifejezett és kinyilvánított (az a kapcsolat, ami kettőnk, és az „Emberiség”, vagy ,az emberi faj” között létesül, amennyiben ez a témánk); vagy hallgatólagos és implicit (az, ami közöttünk létezik, amikor te és én, ahogy az gyakran történik, valójában nem te és én vagyunk, hanem das Man, a deperszonalizált, korlátolt egzisztencia „akárkije”). Ebből a szempontból, az „akárki” az ők, amikor te és én ők vagyunk. Azaz, amikor úgy beszélünk, mint „akárki” beszél, úgy eszünk, mint „akárki” eszik, és úgy sétálunk, mint „akárki” sétál; ami gyakran elkerülhetetlen lesz, mert kapcsolatunk során, te és én nem lehetünk állandóan te és én. ${ }^{9}$

Befejezésként az az területe maradt: nagyon terjedelmes töredéke annak, ahogyan te és én viselkedünk vagy viselkedhetünk duális relációnkban. ${ }^{10}$ Ha te és én, rólad vagy rólam beszélünk, valóságunk az-t hoz létre. Ha egy barátról, a Jupiter bolygóról vagy Velázquez festményéről beszélgetünk,

\footnotetext{
${ }^{9}$ Pusztán deskriptív és szociológiai szempontból, az első a „mi” területének (in-group vagy we-group) elhatárolása az ,ők” területétől (out-group vagy they-group). Ld. W. G. Sumner: Folkways címü könyvében. (Boston, 1907)

${ }^{10}$ Természetesen nincs szó arról, hogy ez az „Az” (das Es), amiről Groddeck óta beszélnek a pszichoanalitikusok, habár bizonyos kapcsolat megfigyelhető közöttük.
} 
az-okba alakul át a barát, a bolygó és a festmény valósága. Az „az” és a „tárgy” fenomenológiailag felcserélhető terminusok. ${ }^{11}$

Az az-zal szemben lehetséges-e egy mi? E névmás felsorolt öt értelme mellett, előfordulhat-e más, amelybe nem perszonális realitások lépnek be? Egy kő, egy fa vagy egy ló előtt, te és én mondhatunk-e mi-t, ami — mint passzív vagy aktív alany — mélyében egybefoglal követ, fát, lovat? Kétség kívül igen, de ilyen esetekben a névmás alkalmazásának indirekt jelentése extenzív vagy metaforikus. Egy sivatagi vándor jogosan mondhatja: ,a lovamat és engem, minket elemészt a szomjúság". A fizikus okkal és nem igaztalanul mondja: ,a kő és én súlyt nyomunk”. A ló és a vándor ekkor egy passzív mi-ben egyesül: egyik is, és másik is közösen szenvednek a szomjúságtól. A fizikust és a követ egy aktív mi köti össze: egyik is, és másik is súlyt nyom. Mégis, nem nehéz felhívni a figyelmet arra, hogy a mi névmás az első esetben „állatokat”, és a másodikban „materiális testeket” nevez meg; végeredményben ,entitásokat” említ. Rólam, rólad, a lóról, a kőről mindig lesz lehetőségünk azt mondani, hogy „vagyunk”.

A probléma még nem fejeződik itt be, mert egy extenzív mi valódi értelme attól függ majd, hogy mit értek ,entitás” és „van” alatt. A kő, a ló, te és én miként vagyunk úgy, hogy minden mi valóságát ezzel az igével

nevezhessük meg? A metafizika egész története feltárul e kérdés előtt. Egy rögtönzött válasz itt elég merész vállalkozás lenne, annál is inkább, minthogy ez az óriási téma — az entitás homogeneitása és analógiája határozottan meghaladja e tanulmány kereteit. Mégis feltehető a kérdés: a kő saját müködésének jelentése, és az ember saját müködésének jelentése között van-e egy hasonlósági reláció, ami igazolja analogikus és metaforikus egyesítésüket egy ugyanazon mi-ben? Ferences módon fivérnek (frate) hívni a Napot, és nővérnek (sor) a vizet: egy lelkesedő és áradó pánfilizmus kifejeződése csupán? Nem hiszem. Ha egy metafizika azt vallja, hogy a világ entitásai egy személyes Isten által teremtett valóságok, és aktivitásának megfelelően folyamatszerüen Ö hozzá rendezettek; ha minden teremtmény ,nyög, mint szülési fájdalomkor” (Rom. VIII, 22) a tökéletesség reményében, amit az emberen keresztül kell elérnie; akkor a mi, ami összefüz engem a kővel és a lóval, mélyében birtokol — mint Szent Tamás mondaná - egy ratio executionist (Summa Theol., I,q. 103, a.6). Élő személynek érezve magam, és élettelen matériának érezve a

\footnotetext{
${ }^{11} \mathrm{Az}$ az területe a $m i$-re való utalása szerint szerveződik egy determinált $̋$-re vagy ők-re a „pragmatikus mezőben”. A ,pragmatikus mező” fogalmáról ld. Ortega: El hombre y la gente. 107
} 
kovakövet, az egyik és a másik, ha megengedik ezt a szófordulatot, „útitársak” vagyunk, és ebben az úti-barátság-metafizikában van Szent Ferenc keresztény metaforáinak és Martin Buber haszid töprengéseinek végső konzisztenciája. A hegeli identifikáló mi, és a sartre-i pusztán élményszerủ mi között, egy gazdag és ígéretes panoráma tárul fel szemünk elött.

[Fordította: Rákosi Marianna] 